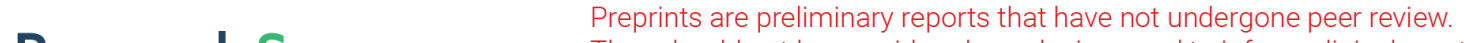 They should not be considered conclusive, used to inform clinical practice, or referenced by the media as validated information. \\ Carbon Dioxide Emissions, Urbanization Level and Industrial Structure: Empirical Evidence from North China
}

\section{Zhuoya Siqin ( $\square$ sqzhuoya@163.com )}

North China Electric Power University - Beijing Campus: North China Electric Power University

Dongxiao Niu

North China Electric Power University - Beijing Campus: North China Electric Power University

Mingyu Li

North China Electric Power University

\section{Hao Zhen}

North China Electric Power University - Beijing Campus: North China Electric Power University

Xiaolong Yang

North China Electric Power University - Beijing Campus: North China Electric Power University

\section{Research Article}

Keywords: carbon dioxide emissions, urbanization level, industrial structure, panel econometric techniques, North China

Posted Date: April 23rd, 2021

DOl: https://doi.org/10.21203/rs.3.rs-342919/v1

License: (c) (1) This work is licensed under a Creative Commons Attribution 4.0 International License. Read Full License

Version of Record: A version of this preprint was published at Environmental Science and Pollution Research on January 17th, 2022. See the published version at https://doi.org/10.1007/s11356-02117373-x. 


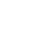

\title{
Carbon Dioxide Emissions, Urbanization Level and Industrial Structure: Empirical Evidence from North China
}

(1)

\author{
Zhuoya Siqin ${ }^{a}$, Dongxiao Niu ${ }^{{ }^{*}}$, Mingyu Li ${ }^{a}$, Hao Zhen ${ }^{a}$, Xiaolong Yang ${ }^{a}$
}

a:School of Economics and Management, North China Electric Power University , Beijing, 102206, China

sqzhuoya@163.com (Z.S);niudx@126.com (D.N); 15210158697@163.com (M.L); mailofzhenhao@163.com (H.Z);

yangxiaolong@neepu.edu.cn (X.Y)

\begin{abstract}
This paper aims to examine the nexus among carbon dioxide $\left(\mathrm{CO}_{2}\right)$ emissions, urbanization level and industrial structure in North China over the period 2004-2019, according to an expanded Cobb-Douglas production function. The panel econometric techniques are employed to complete the empirical analysis, including cross-sectional correlation test, panel unit root test, panel cointegration test and panel Granger causality test. The empirical results support the long-term equilibrium relationship among $\mathrm{CO}_{2}$ emissions, urbanization level and industrial structure in North China, and the urbanization level contributes most to $\mathrm{CO}_{2}$ emissions, followed by fossil energy consumption. Furthermore, the bidirectional causality between $\mathrm{CO}_{2}$ emissions and urbanization level and unidirectional causality from industrial structure to $\mathrm{CO}_{2}$ emissions are found in North China, indicating that urbanization level and industrial structure have significant impacts on $\mathrm{CO}_{2}$ emissions. Finally, according to the empirical findings, several policy suggestions are proposed for the purpose of reducing $\mathrm{CO}_{2}$ emissions in North China.
\end{abstract}

Keywords: carbon dioxide emissions; urbanization level; industrial structure; panel econometric techniques; North China

\section{Introduction}

In recent years, the world's climate has gradually warmed. We have experienced warm winters one after another, and some countries are experiencing an unprecedented crisis. The main cause of climate warming is the emissions of greenhouse gases, of which the most one is $\mathrm{CO}_{2}$. China, a country with the largest $\mathrm{CO}_{2}$ emissions in the world, will reach $27 \%$ of global $\mathrm{CO}_{2}$ emissions in 2017. China is deeply aware of the urgency of reducing $\mathrm{CO}_{2}$ emissions. To achieve the goal of low-carbon economic development, china submitted "strengthening action on climate change - China's national independent contribution" (hereinafter referred to as "national independent contribution") in 2015, publicly committed that its $\mathrm{CO}_{2}$ emissions will reach the peak around 2030, and strive to reach the peak as soon as possible. On September 22, 2020, at the general debate of the 75th UN General Assembly, China proposed to enhance the national independent contribution, adopt more powerful policies and measures, strive to reach the peak of $\mathrm{CO}_{2}$ emissions by 2030 , and strive to achieve carbon neutrality by 2060 . The research on $\mathrm{CO}_{2}$ peaking in China is becoming more and more important and urgent. North china, including Beijing, Tianjin, Hebei, Shanxi and Inner Mongolia, is an important part of China's economy. In 2019, North China's GDP accounted for $13.85 \%$ of the total GDP of China, while carbon emissions in North China accounted for $21.78 \%$ of China's total. With the increase of $\mathrm{CO}_{2}$ emissions, reducing the carbon emissions intensity in North China is very important for low-carbon development. Based on this, researching the relationship among carbon emissions and economic growth in the North of China can promote a benign transformation of economic growth patterns in this region. The early realization of a low-carbon economic development path will eliminate the link between carbon emissions and economic growth, and is of positive significance to China's energy conservation and emission reduction.

With the continuous expansion of global warming, extensive economic development mode is no longer applicable, which requires us to reduce energy consumption and improve utilization rate. Therefore, low-carbon economic development path has become the focus of the world. Regions such as Beijing, Tianjin and Hebei not only play an important 
role in the geographical location but also a major impact on China's economic development. The integration of Beijing, Tianjin and Hebei has made this region more and more important. The planning of low-carbon economy for the whole region can truly solve the carbon emissions problems and make the region achieve sustainable development. It is worth noting that North China is a key area of China's urbanization and industrial restructuring, revealing that the urbanization and industrial restructuring in this region can significantly change China's economic development mode, improve the quality of economic development, and provide a demonstration effect for other regions to achieve low-carbon development. Therefore, this article explores the relationship between carbon emissions, urbanization levels and industrial structure in North China, and aims to provide a reference for formulating carbon emission reduction policies from the perspective of urbanization and industrial structure. In general, the main contributions of this article are:

(1) In previous studies on the link among carbon emissions and economic growth, the absolute value of each variable was often used as the research object, so that the results could only reflect the overall trend and could not further describe the internal relationship between variables. Therefore, this paper introduces relative variables such as carbon emission intensity, energy consumption structure and GDP per capita, and expands the traditional Cobb-Douglas production function, which can reveal the internal connection between carbon emissions, economic growth and energy consumption.

(2) According to panel data of five provinces in North China, this paper studies the relationship among the above three variables. At the same time, considering the relevant industrial and economic development status, this paper add industrial structure and urbanization rate into the model, which can truly reflect the relationship between carbon emissions, energy consumption and economic growth under the background of China's new normal economic development. Meanwhile, the empirical results provide a reference for the development of carbon reduction policy of urbanization and industrial structure perspective.

The rest of this article is organized as follows. The related literature is introduced in Section 2. Section 3 introduces the methods that this paper needs. Section 4 reports the data sources and empirical analysis. Finally, we summarize the conclusions and propose some policy proposes in Section 5.

\section{Literature Review}

Before studying the relationship between fossil energy consumption, industrial structure, urbanization rate, per capita GDP and carbon dioxide emissions in China, it is necessary to use the previous research results as references. A large amount of literature has analyzed the relationship between energy consumption and economic growth, depicting the nature character and the causal relationship. Kraft J and Kraft A (1978) were the earliest to study the relationship between economic growth and energy consumption and found a unidirectional causal link between GNP and energy consumption I. However, Akarca A. T and Long T. V (1980), by changing the data interval to two years in the same date, found that no causation between GNP and energy consumption. Later, more and more scholars have begun to study the relationship between these two variables, and the results can be distinguished by four hypotheses:

(1) Growth hypothesis. This shows that there is a one-way causal relationship between energy consumption and economic growth, which shows that the economic system is an energy-dependent economy. In other words, increasing energy consumption will promote real GDP growth and more aggressive energy policies should be adopted to drive economic development. The empirical results of the literature (Wang Y et al. 2011; Vafaeirad M 2015; Chaudhry I S 2015) display a unidirectional causal link from energy consumption to economic growth.

(2) Conservation hypothesis. This shows that economic growth has a one-way causality to energy consumption, which means that the government issuance of energy conservation policies at the right moment can reduce energy consumption, but it will not affect the growth of real GDP. References (Narayan P K 2012; Qazi U 2021; Li Y et al.2020; Ozturk I 2010) point out the causal relationship between two variables.

(3) Neutrality hypothesis. This shows that changes in energy consumption have little or no impact on economic growth. Besides, economic development will not affect energy consumption. Thus, the policy of saving energy has no unfavorable 

2015) clearly pointed out that there is no causal relationship between economic growth and energy consumption.

(4) Feedback hypothesis. This indicates that energy consumption is likely have bidirectional causation with economic growth, and the government should actively improve the efficiency of energy utilization. References (Wang S et al.2016; Etokakpan M U 2020; Kahia M et al.2017; Amri F 2017) discover that these two variables maintained two-way causality.

According to the research above, we found that the relationship between energy consumption and economic growth in different countries and regions is completely different. With the deepening of research, even in the same country, the corresponding direction and causal relationship quit diversity. The main reason are: (1) Different economic development methods and different industrial structures are significantly different in different countries or regions. (2) Different stages of development in the same country adopt different energy and economic intervention measures, such as adjusting energy consumption structure and adopting measures to reduce emissions and save energy. Therefore, the conclusions of different periods are also different; and (3) Different techniques in modeling will also produce various conclusions.

Researchers have widely adopted Pedroni $(1999 ; 2004)$ panel cointegration method to study the long-term relationship between energy consumption and economic growth. J Li and L Chen (2018) used panel co-integration to study the relationship between investment demand, Gross Domestic Product, population scale, electricity consumption and installed electrical capacity for China during the 2004-2016 periods. Farhani (2013) studied the relationship between carbon dioxide emissions, urbanization, GDP and energy consumption of 11 MENA countries using panel data method, and Farhani found that more the sources of energy use and greater trade opening to the outside tend to cause more carbon dioxide emissions, and the improvement in the level of urbanization in environmental functions has a positive impact on reducing pollution levels. Catia Cialani (2017) using the panel unit root, cointegration and Granger causality to study the relationships among per capita carbon dioxide emissions, GDP and international for 150 countries during the 1960-2008 period. The results show that there is a two-way short-term causal relationship between international trade and GDP per capita. Eyup Dogan and Alper Aslan (2017) used cross-sectionally dependent heterogeneous panel estimation techniques to explore the link between carbon dioxide emissions, GDP, energy consumption and tourism in the EU and candidate countries during the period of 1995-2011. Usama Al-mulai (2014) studied the relationship between consumption and GDP growth of nuclear energy and carbon dioxide emissions of 30 major consumer of nuclear energy using Granger causality test and panel data methods, and employing Granger causality test and panel data method. The results showed that the consumption of nuclear energy plays a significant role in the growth of GDP but has make no difference on carbon dioxide emissions. MN Esfahani and E Rasoulinezhad (2015) used group cointegration, FMOLS and DOLS groups and studied the relationship between oil consumption, GDP and $\mathrm{CO}_{2}$ emissions in the next 11 (N-11) countries from 1980 to 2013, and the results showed that there is a long-term two-way relationship between GDP per capita oil consumption and $\mathrm{CO}_{2}$ emissions. I Saleh and $\mathrm{S}$ Abedi (2014) studied the link among carbon dioxide emissions and GDP using panel date and the Vector Auto-Regression Model and found that a bidirectional causality relationship among carbon dioxide emissions and GDP for three groups of countries. Kais Sadi and Ben Mbarek (2016) studied the relationship between factors such as carbon dioxide emissions and GDP per capita during 1990-2013 period using Pedroni's method in nine developed countries.

Because of the problem of global warming is becoming more and more serious, many researchers in the study of the relationship between energy consumption and economic growth has begun to consider carbon dioxide emissions. Recently, experts conducted more in-depth studies by examining the relationship among industrial structure. For instance, Yuan Wang studied the link between carbon dioxide emissions, energy use and urbanization in the Association of Southeast Asian Nations countries (2016) BRICS (2016), and Bhat T A (2020) tudied the link between saving and economic growth, using panel co-integration etc. These papers show that the results of causality between different countries are different, so a unified energy policy will not be a good strategy for widespread implementation. Moreover, JLS Lim(2017) and Sulaiman C (2017) employed different methods to analyze the relationship in Malaysia, and reached a similar conclusion: There is a one-way relationship in $\mathrm{CO}_{2}$ emissions to economic growth in the long run. In addition, for new EU member states and 
candidate countries. The results show that there is a one-way causality from trade openness, energy consumption and urbanization to carbon dioxide emissions, from energy consumption, urbanization and GDP to trade (Kasman A 2015). Finally, for 14 MENA countries, Salari M (2021) using simultaneous-equation models for testing the relationship among carbon dioxide emissions and energy consumption, and found that there is a bidirectional causal relationship among these variables.

To better understand the relationship among industrial structure, energy consumption structure, urbanization rate, per capita GDP and $\mathrm{CO}_{2}$ emissions, the production function of Cobb-Douglas is introduced in (Cobb C W et al.1928). This production function is used as a department model, with the research object as the department and the department output as the explanatory variable. The major control variables are energy consumption, industrial structure and population density playing an important role in the output. It also introduces other variables in the model that may affect the output. Based on the estimation of the model, the contribution of these input variables to output is analyzed, and the purpose of the study is achieved (Van G 2021). Ouyang (2017), Wang and Fang (2014) and Xu (2016) analyzed the influences of urbanization on carbon dioxide emissions and found a bi-directional causal relationship among carbon dioxide emissions, urbanization and energy consumption: specifically. There is a two-way positive causal link between urbanization and carbon dioxide emissions exists, and a same correlation exists in them. Khalid (2016) and Margarita (2016) explored the relationship among carbon dioxide emissions and tourism of Portuguese during 2000-2008 and found that tourism activity has an important effect to carbon intensity. Kofi Baah (2017) employed Johansen co-integration model for China during 19702014 period. The results show that there is a long-term N-shaped relationship between economic growth, carbon dioxide emissions and international tread, under the estimated Kuznet curve framework. The effects of land finance and land urbanization on $\mathrm{CO}_{2}$ emissions were studied by Zhang and $\mathrm{Xu}$ (2017) and the literature found that the two variables significantly affect carbon dioxide emissions. There are many factors that affect $\mathrm{CO}_{2}$ emissions, like: industrial structure, energy consumption structure, urbanization rate and per capita GDP, etc. However, most of the existing studies involve only a few of factors, which are not comprehensive. Moreover, there is not much research on the causality relationship between these variables. Therefore, a multivariable model based on Cobb Douglas production function is proposed in this paper. Because the panel data model can effectively solve the problem of sample shortage and consider time series data and cross-sectional data, it helps to correctly estimate the relationship between variables and improve the importance of model estimation (2012). For accurate comparison of the contribution of each variable to carbon dioxide emissions in the five provinces, including Hebei, Shanxi, Beijing, Inner Mongolia and Tianjin, we analyze causality and co-integration relationship between those variables in different provinces panel data model.

\section{Methodology}

\subsection{Production Function Model}

A single-sector economic model that considers $\mathrm{CO}_{2}$ emissions, it is assumed that society as a whole has only one production department and one production function. On the basis of the traditional production function, the $\mathrm{CO}_{2}$ emissions are introduced into the production function, and the concrete form of the model is expressed as follow:

$$
Y=f\left(A(t), L_{t}, H_{t}, R_{t}, W_{t}\right)=A(t) L_{t}^{\alpha} H_{t}^{\beta} R_{t}^{\gamma} W_{t}^{\varepsilon}
$$

where $\mathrm{Y}$ is the output value that is $\mathrm{CO}_{2}$ emissions, $L_{t}^{\alpha}, H_{t}^{\beta}, R_{t}^{\gamma}$ and $W_{t}^{\varepsilon}$ are the fossil energy consumption structure, industrial structure, urbanization rate, per capita GDP, respectively, and $A, \alpha, \beta, \gamma$ and $\varepsilon$ are the constant values.

By changing the original variable in equation (1) to the following logarithmic equation, the effect of heteroscedasticity on the regression result can be prevented:

$$
\ln Y=\ln A+\alpha L_{t}+\beta H_{\mathrm{t}}+\gamma R_{t}+\varepsilon \ln W_{t}
$$

where $\ln Y$ is the natural logarithm of the output, and $\ln A$ means the logarithm of total factor $\mathrm{CO}_{2}$ emissions productivity, $L_{t}$ is energy consumption structure, $H_{t}$ stands for the logarithm industrial structure, $R_{t}$ represent the 
urbanization rate, $\ln W_{t}$ is the logarithm of per capita GDP, and $\alpha, \beta, \gamma, \varepsilon$ are the output elasticities.

If equation (2) considers individual factors and time series factors, the panel data model for each factor of production under the framework of the production function model can be derived from equation (3).

$$
\ln Y_{i}=\ln A_{i}+\alpha_{i} L_{i t}+\beta_{i} H_{i t}+\gamma_{i} R_{i t}+\varepsilon_{i} \ln W_{i t}+\mu_{i t}
$$

where $\mu_{i t}$ is the random error term. It is independent, satisfying the null hypothesis mean value and has the same variance of $\sigma_{\mu}^{2}$. means the number of cross-section, and $t$ stands for time period.

There will be two cases. First, the equation (3) is a fixed effect model when the individual non-observation effects presented by $\ln A_{i}$ is the individual characteristics and do not change with time; Second, the equation (3) is a random effect model, when $\ln A_{i}$ is a random variable and conforms to a specific distribution.

\subsection{Cross-sectional Dependence Test}

Neglecting the cross-section data correlation will lead to low efficiency and invalid test statistics. Hence, before a series of empirical analysis is carried out, it is necessary to test whether the cross-sectional is dependence. The spatial error regression model can be expressed as follows:

$$
y_{i t}=X_{i t}^{\prime} \beta+u_{i t}, i=1,2, \cdots, N, \mathrm{t}=1,2, \cdots, \mathrm{T}
$$

where $u_{i t}$ means the regression error perturbation term with random individual effect. According to Anselin (1988), there are:

$$
\begin{gathered}
u_{i}=\mu+\varepsilon_{t} \\
\varepsilon_{t}=\lambda W \varepsilon_{t}+v_{t}
\end{gathered}
$$

where $\mu=\left(\mu_{1}, \mu_{2}, \ldots, \mu_{N}\right), \mu \sim \operatorname{IIN}\left(0, \sigma^{2}\right), v_{t}^{\prime}=\left(v_{t 1}, v_{t 2}, \ldots, v_{t N}\right), v_{i t} \sim I I N\left(0, \sigma_{v}^{2}\right)$, and $v_{t}$ and $\mu$ are independent of each other. In formula (6), if $|\lambda|<1, W$ is a space weight matrix with all zero diagonal elements of $N \times N$ dimension, besides satisfies $\left(I_{N}-\lambda W\right)$ is a non-degenerate matrix.

Cross-sectional dependence test, that is, to check the correlation between the $\mathrm{N}$ cross-sections in the panel data. As long as two of the cross-sections are related, it is considered that there is cross-sectional dependence panel date. The null hypothesis of the cross-sectional dependent test can be expressed as below:

$$
H_{0}: \rho_{i j}=\rho_{j i}=\operatorname{cor}\left(u_{i t}, u_{j t}\right)=0, i \neq j
$$

The alternative hypothesis is shown in Equation (8):

$$
H_{1}: \rho_{i j}=\rho_{j i} \neq 0, i \neq j
$$

The test statistics based on uncorrelated regression in Breush and Pagan (1980)is provided by:

$$
\text { where } \hat{\rho}_{i j}=\hat{\rho}_{j i}=\frac{\sum_{t=1}^{T} \hat{u}_{i t} \hat{u}_{j t}}{\left(\sum_{i=1}^{T} \hat{u}_{i t}^{2}\right)^{1 / 2}\left(\sum_{i=1}^{T} \hat{u}_{j t}^{2}\right)^{1 / 2}}
$$

$$
L M=T \sum_{i=1}^{N-1} \sum_{j=i+1}^{N} \hat{\rho}_{i j}^{2}
$$

And $\hat{u}_{i t}$ is the residual estimation of (10). Under the null hypothesis, the asymptotic distribution of the LM test statistics is a $\chi^{2}$ distribution with $N(N-1) / 2$ degrees of freedom. When $N<T$, this test is suitable for the case. When $N>T$, the following two methods can be used for testing.

Pesaran (2004) proposed a simple method to test the cross-section error, which is suitable for the case that the crosssection individuals $\mathrm{N}$ are relatively large and the time $\mathrm{T}$ is relatively small. The test is an average of the correlation coefficients of the residuals that obtained from the OLS regression, and the test statistics are as follows:

$$
C D=\sqrt{\frac{2 T}{N(N-1)}}\left(\sum_{i=1}^{N-1} \sum_{j=i+1}^{N} \hat{\rho}_{i j}\right)
$$


Under the null hypothesis of uncorrelated, the asymptotic limit distribution of $C D$ statistic is normal distribution. Besides Pesaran confirms the superior performance of this test in small examples and it is very suitable for our research.

\subsection{Panel Unit Root Test}

The unit root test should be carried out before the panel data regression analysis, which can avoid spurious regression. There are many methods of unit root test that including LLC test (Levin A et al. 2004), IPS test (Im, K.S 2003), Breitung (Breitung, J. 1999), Hadrid(Hadri, K 2000) and Carrion-i-Silvestre et al.( Lluís Carrion-i-Silvestre 2005). The LCC test method is as below:

$$
\Delta y_{i t}=a_{i}+\delta_{i} t+\gamma_{i} y_{i, t-1}+\sum_{t=1}^{p_{i}} \phi \Delta y_{i, t-1}+\xi_{i t}, i=1, \cdots, N, t=1, \cdots, T
$$

We assume that $\xi_{i t}$ is independent distributed for all $i, \Delta$ represents the first order difference operator $(1-L)$. If $\gamma_{i}=$ 0 , then $y_{i t}$ contains the unit root, while if $\gamma_{i}<0, y_{i t}$ is considered to be stationary. The null hypothesis of LLC and the alternative hypothesis of LCC are as follows:

$$
\begin{gathered}
H_{0}: \gamma_{1}=\gamma_{2}=\cdots \gamma_{N}=0 \\
H_{1}: \gamma_{1}=\gamma_{2}=\cdots=\gamma_{N}=\gamma<0
\end{gathered}
$$

To test the null hypothesis $H_{0}$ and the alternative hypothesis $H_{1}$, Levin and Lin suggest that we should make a regressing of $\Delta y_{i t}$ and $y_{i, t-1}$ for each $i$ relative to the other variables in Equation (12) firstly and obtain residuals $\hat{e}_{i t}$ and $\hat{v}_{i, t-1}$, respectively. Secondly, the regression estimate of Equation (15) is $\gamma$.

$$
\hat{e}_{i t}=\gamma \hat{w}_{i, t-1}+\xi_{i t}
$$

The $t$ statistic for test $\gamma=0$ is as follows:

$$
t_{\gamma}=\frac{\tilde{\gamma}}{s d_{\tilde{\gamma}}}
$$

Where the $\tilde{\gamma}$ is the least square estimate of Equation (15),

$$
\begin{aligned}
& s d_{\tilde{\gamma}}=\hat{\sigma}_{\varsigma}\left[\sum_{i=1}^{N} \sum_{t=p_{i}+2}^{T} \tilde{v}_{i, t-1}^{2}\right]^{-\frac{1}{2}} \\
& \hat{\sigma}_{\varsigma}^{2}=(N \tilde{T})^{-1} \sum_{i=1}^{N} \sum_{t=p_{i}+2}^{T}\left(\tilde{e}_{i t}-\tilde{\gamma}_{i, t-1}\right)^{2} \\
& \bar{p}=\frac{1}{N} \sum_{i=1}^{N} p_{i}, \tilde{T}=(T-\bar{p}-1)
\end{aligned}
$$

The IPS test sets the alternative hypothesis to the following equation:

$H_{A}^{*}$ : at least one i satisfies $\gamma_{\mathrm{i}}<0$

This hypothesis broadens the strong assumption that Levin and Lin require Equation (12) to be homogeneity under the alternative hypothesis. Therefore, the IPS test cannot use mixed data, and the ADF unit root test should be performed for each individual in the $N$ cross-sections, respectively.

The Hadri test is similar to time series KPSS test. $H_{0}$ : none of the sequences in the panel data contain unit roots. Considering the back-end residual sequence of the original panel data, define the LM statistic, which contains two types of statistics: drift term and trend term. The formula is as follows:

$$
L M_{1}=\frac{1}{N}\left[\sum_{i}^{N}\left[\sum_{t} S_{i}(t)^{2} / T^{2}\right] / f_{0}\right]
$$




$$
L M_{2}=\frac{1}{N}\left[\sum_{i}^{N}\left[\sum_{t} S_{i}(t)^{2} / T^{2}\right] / f_{i 0}\right]
$$

where $S_{i}(t)=\sum_{s=1}^{t} \hat{u}_{i t}$ is the residual accumulated function, $f_{0}$ is the residual spectral density when the frequency is 0 . Considering cross-section heterogeneity, $L M_{2}$ is chosen as a test statistic.

Under the condition of $H_{0}$, the asymptotic distribution of the statistic $Z=\sqrt{N}(L M-\xi) / \varsigma$ is the normal distribution.

\subsection{Panel Co-integration Test}

Only after the unit root test indicates that the series is stable can the panel co-integration test be performed by Pedroni [22] co-integration test theory. The theory holds that cross-sectional independence is related to different individual effects. It is used as below:

$$
\Psi_{i t}=\alpha_{i t}+\delta_{i} t+\gamma_{1 i} L_{i t}+\gamma_{2 i} K_{i t}+\gamma_{3 i} H_{i t}+\gamma_{4 i} R_{i t}+\gamma_{5 i} W_{i t}+\varepsilon_{i t}
$$

where $t=1,2, \cdots, T$ represents the time period, $i=1,2, \cdots, N$ represents the country or region in the panel date. The parameter $\alpha_{i t}$ is the likelihood of fixed effects and $\delta_{i}$ is the deterministic trends in specified-country or specifiedregion, $\varepsilon_{i t}$ means the estimated residual, which is a departure from long-term relationships. When some variables are expressed in the form of natural logarithms, the parameters $\gamma_{1 i}, \gamma_{2 i}, \gamma_{3 i}, \gamma_{4 i}, \gamma_{5 i}$ in Equation (12) can be interpreted as elastic coefficients. In order to test the null hypothesis that there is no co-integration, that is, $\rho_{i}=1$, the later unit root test of the residuals is expressed as follows:

$$
\varepsilon_{i t}=\rho_{i} \varepsilon_{i t-1}+\omega_{i t}
$$

Pedroni proposed two co-integration test sets [21-22]. The method of panel testing based on internal dimension includes panel $\rho$-statistic, $v$-statistic, ADF-statistic and PP-statistic. These statistics use the auto-regressive coefficients of different countries or regions to estimate the unit root test of the residuals. Statistics take the common time and the heterogeneity of countries or regions into account. The group test based on the between dimension method includes group PP-statistic, group ADF-statistic and group $\rho$-statistic. These statistics based on the average of the auto-regressive coefficients for each group. In the panel, the auto-regressive coefficient is related to the unit root test of the residuals for each country or region. These seven statistics are asymptotically standard distributions. When Pedroni test shows that there is co-integration relation among variables, fixed effect estimation and causality test can be carried out.

\subsection{Panel Causality Test}

Engle and Granger proposed that an un-directional or a bi-directional Granger Causality will exit in two variables if there is co-integration between the two variables in the long term. Besides, Granger causality test is widely applied in studying causality between variables. In the case of time series, Granger defines the causal relationship between two economic variables $X$ and $Y$ as follows: under the past information contains variables $X$ and $Y$ conditions, the prediction result of variable $Y$ is better than that conducting the past information of $Y$ alone, that is, the variable $X$ can help us explain the future change of the variable $Y$, so $X$ is considered as the Granger cause of $Y$. This paper uses Granger model to analyze the causal relationship between time series:

$$
\begin{array}{r}
y_{t}=\alpha_{0}+\sum_{i=1}^{m} \alpha_{i} y_{t-i}+\sum_{i=1}^{m} \beta_{i} x_{t-i}+\varepsilon_{t} \\
x_{t}=\alpha_{0}+\sum_{j=1}^{n} \alpha_{j} y_{t-j}+\sum_{j=1}^{n} \beta_{j} x_{t-j}+\varepsilon_{t}
\end{array}
$$

The equation (26) represents the null hypothesis of the tests, that is, $X$ is not the Granger cause of $Y$. If equation (26) is rejected, we can conclude that $X$ Granger caused $Y$. Meanwhile, it can be concluded that $Y$ Granger caused $X$ when formula (27) is rejected: 


\section{Data and Empirical Analysis}

\subsection{Data Source and Descriptive Statistics}

This paper adopts panel data of North China, including Hebei, Shanxi, Beijing, Tianjin, and Inner Mongolia, over the period of 2004-2019. The model proposed in this paper involves five variables, namely, fossil energy consumption (Fes), industrial structure (S), urbanization rate (Ur), per capita GDP (pcGDP) and $\mathrm{CO}_{2}$ emissions (CE). We obtained these data from the website of China National Bureau of Statistics. In order to avoid drastic fluctuations in the data and eliminate the heterodyne phenomenon in the time series, some variables are transformed in the nature logarithmic series, such as lnCE and lnpcGDP. At the same time, the coefficient of the logarithmic model can represent the elasticity of the variable.

The summary statistics of $\operatorname{lnCE}, \mathrm{Ur}, \mathrm{S}$, lnpcGDP and Fes are presented in Table 1 . The mean of $\mathrm{CO}_{2}$ emissions ranges from 4.73 in Beijing to 6.25 in Shanxi. As for the per capita GDP, Shanxi has the lowest per capita GDP, whereas Beijing has the highest. Based on the urbanization rate, which is defined as the ratio of urban population to the total population, Beijing has the highest urbanization rate, while Hebei is the lowest in the panel. In realizing industrial structure, which is displayed by the proportion of the added value of the secondary industry to GDP, Hebei has the highest industrial structure because there are many heavy industrial enterprises in Hebei, and Beijing has the lowest industrial structure among five provinces. Regarding the fossil energy consumption, Shanxi has the highest ratio, whereas Beijing has the lowest in North China.

Table1 Summary statistics of time series variables

\begin{tabular}{|c|c|c|c|c|c|c|}
\hline & Variable & Mean & Median & Maximum & Minimum & S.D \\
\hline \multirow{5}{*}{$\begin{array}{l}\text { North } \\
\text { China }\end{array}$} & $\operatorname{lnCE}$ & 5.60222 & 5.61730 & 6.73723 & 4.36990 & 0.78545 \\
\hline & $\mathrm{Ur}$ & 0.59515 & 0.53595 & 0.86500 & 0.26220 & 0.18607 \\
\hline & $\mathrm{S}$ & 0.45814 & 0.50539 & 0.58622 & 0.19738 & 0.11083 \\
\hline & lnpcGDP & 3.53101 & 3.69861 & 5.02108 & 1.62187 & 0.91146 \\
\hline & Fes & 0.68443 & 0.74011 & 0.96710 & 0.12146 & 0.23264 \\
\hline \multirow{5}{*}{ Beijing } & $\operatorname{lnCE}$ & 4.72664 & 4.75615 & 4.87396 & 4.53505 & 0.11804 \\
\hline & $\mathrm{Ur}$ & 0.83787 & 0.84700 & 0.86500 & 0.77640 & 0.02846 \\
\hline & $\mathrm{S}$ & 0.25679 & 0.24445 & 0.32555 & 0.19738 & 0.04023 \\
\hline & lnpcGDP & 6.93703 & 6.93294 & 7.16415 & 6.69938 & 0.16999 \\
\hline & Fes & 0.31791 & 0.32471 & 0.46124 & 0.12146 & 0.10155 \\
\hline \multirow{5}{*}{ Tianjin } & $\operatorname{lnCE}$ & 4.87364 & 4.86277 & 5.27839 & 4.36990 & 0.32638 \\
\hline & $\mathrm{Ur}$ & 0.77330 & 0.76770 & 0.82640 & 0.72020 & 0.03673 \\
\hline & $\mathrm{S}$ & 0.52029 & 0.52151 & 0.55213 & 0.46584 & 0.02487 \\
\hline & $\operatorname{lnpcGDP}$ & 4.02475 & 4.10635 & 5.02108 & 2.79589 & 0.76104 \\
\hline & Fes & 0.56234 & 0.54824 & 0.71215 & 0.39250 & 0.10017 \\
\hline \multirow{5}{*}{ Hebei } & $\operatorname{lnCE}$ & 6.31048 & 6.43459 & 6.73730 & 5.58642 & 0.41510 \\
\hline & $\mathrm{Ur}$ & 0.40074 & 0.41076 & 0.51330 & 0.26220 & 0.07717 \\
\hline & $\mathrm{S}$ & 0.51403 & 0.51978 & 0.54343 & 0.48268 & 0.01942 \\
\hline & lnpcGDP & 5.83782 & 5.83197 & 5.88926 & 5.78263 & 0.03812 \\
\hline & Fes & 0.75144 & 0.74011 & 0.87474 & 0.69345 & 0.05934 \\
\hline Shanxi & $\operatorname{lnCE}$ & 6.24596 & 6.31063 & 6.55757 & 5.61223 & 0.28786 \\
\hline
\end{tabular}




\begin{tabular}{cllllll} 
& Ur & 0.44989 & 0.44571 & 0.55030 & 0.35060 & 0.06301 \\
& S & 0.52131 & 0.53457 & 0.58622 & 0.40687 & 0.04926 \\
& lnpcGDP & 2.96725 & 3.12562 & 3.90000 & 1.62187 & 0.79291 \\
& Fes & 0.89984 & 0.89850 & 0.91725 & 0.88604 & 0.01071 \\
\hline \multirow{2}{*}{ Inner } & $\operatorname{lnCE}$ & 5.85437 & 6.09040 & 6.52609 & 4.72471 & 0.66681 \\
Mongolia & Ur & 0.51394 & 0.50930 & 0.60300 & 0.42820 & 0.06082 \\
& S & 0.47831 & 0.50098 & 0.55973 & 0.37851 & 0.06531 \\
& $\operatorname{lnpcGDP}$ & 3.39281 & 3.56917 & 4.61202 & 1.77605 & 1.01522 \\
& Fes & 0.89063 & 0.88440 & 0.96710 & 0.81440 & 0.04737 \\
\hline
\end{tabular}

Prior to empirical analysis, a correlations test should be conducted on the panel data. The results of correlations test for the panel data are listed in Table 2. As shown in the table, the test results, at $1 \%$ level of significance or $10 \%$ level of significance, reject the null hypothesis. Therefore, there is a statistical correlation between variables.

Table 2 Correlations for the panel data set ( $\mathrm{p}$ values in parentheses)

\begin{tabular}{llllll}
\hline & LnCE & LnpcGDP & S & Ur & Fes \\
\hline LnCE & 1.0000 & & & \\
LnpcGDP & -0.6218 & & & \\
& $(0.0000)^{* * *}$ & 1.0000 & & & \\
S & 0.6046 & -0.2147 & & & \\
& $(0.0000)^{* * *}$ & $(0.0559)^{*}$ & 1.0000 & & \\
Ur & -0.6914 & 0.7259 & -0.5551 & & \\
& $(0.0000)^{* * *}$ & $(0.0000)^{* * *}$ & $(0.0000)^{* * *}$ & 1.0000 & \\
Fes & 0.6317 & -0.6289 & 0.7013 & -0.8568 & \multirow{2}{*}{1.0000} \\
& $(0.0000)^{* * *}$ & $(0.0000)^{* * *}$ & $(0.0000)^{* * *}$ & $(0.0000) * * *$ & \\
\hline
\end{tabular}

Notes: * Denotes $10 \%$ level of significance; $* * *$ Denotes $1 \%$ level of significance.

\subsection{Results of Cross-sectional Dependence Test}

The results of Pesaran cross-sectional dependence test are listed in Table 3. As shown in the table, the test results, at $5 \%$ level of significance, accept a null hypothesis with no cross-sectional dependence. Therefore, the first-generation unit root tests including Im, Pesaran and Shin W-stat (IPS) test, Levin, Lin \& Chu (L.L\&C) $t$-test, Phillips-Perron Fisher (PPFisher) test and Augmented Dickey Fuller-Fisher (ADF-Fisher) test can be used to test the stationary of different variables.

Table 3 Pesaran cross-sectional dependence test results.

\begin{tabular}{lll}
\hline Cross-Sectional Dependence Test & Pesaran's Test of Cross-Sectional Independence & p-Value \\
\hline Pesaran cross-sectional dependence test & -1.790 & $0.0735^{* *}$ \\
\hline
\end{tabular}

Notes: ** Denotes $5 \%$ level of significance.

\subsection{Results of Panel Unit Root Test}

It is necessary to check the stationary of these variables before the panel co-integration is used to test the long-term relationship between the fossil energy consumption, industrial structure, urbanization rate, per capita GDP in the five provinces of North China. The commonly used methods of unit root test are Im, Pesaran and Shin W-stat (IPS) test, Levin, Lin \& Chu (L.L\&C) $t$-test, Phillips-Perron Fisher (PP-Fisher) test and Augmented Dickey Fuller-Fisher (ADF-Fisher) test. Obviously, from the results of the unit test in Table 4, it can be seen that these variables are not stationary in level forms. 
Table 4 Panel data unit root test results (p-values in parentheses)

\begin{tabular}{|c|c|c|c|c|c|c|}
\hline Form & Variable & LLC & IPS & ADF-Fisher & PP-Fisher & Conclusion \\
\hline \multirow{5}{*}{ Level } & LnCE & $\begin{array}{l}2.46140 \\
(0.9931)\end{array}$ & $\begin{array}{l}2.72231 \\
(0.9968)\end{array}$ & $\begin{array}{l}2.22710 \\
(0.9943)\end{array}$ & $\begin{array}{l}6.60561 \\
(0.7621)\end{array}$ & Non-stationary \\
\hline & LnpcGDP & $\begin{array}{l}4.21713 \\
(1.0000)\end{array}$ & $\begin{array}{l}5.10981 \\
(1.0000)\end{array}$ & $\begin{array}{l}0.77700 \\
(0.9999)\end{array}$ & $\begin{array}{l}7.64333 \\
(0.6636)\end{array}$ & Non-stationary \\
\hline & $\mathrm{S}$ & $\begin{array}{l}3.61775 \\
(0.9999)\end{array}$ & $\begin{array}{l}4.73665 \\
(1.0000)\end{array}$ & $\begin{array}{l}4.59892 \\
(0.9163)\end{array}$ & $\begin{array}{l}1.70636 \\
(0.9981)\end{array}$ & Non-stationary \\
\hline & $\mathrm{Ur}$ & $\begin{array}{l}-1.95382 \\
(0.0254)^{* *}\end{array}$ & $\begin{array}{l}-1.04417 \\
(0.1482)\end{array}$ & $\begin{array}{l}12.9137 \\
(0.2285)\end{array}$ & $\begin{array}{l}4.69817 \\
(0.9104)\end{array}$ & Non-stationary \\
\hline & Fes & $\begin{array}{l}1.86711 \\
(0.9691)\end{array}$ & $\begin{array}{l}2.69557 \\
(0.9965)\end{array}$ & $\begin{array}{l}4.90453 \\
(0.8975)\end{array}$ & $\begin{array}{l}10.1427 \\
(0.4281)\end{array}$ & Non-stationary \\
\hline \multirow{5}{*}{$\begin{array}{l}\text { First } \\
\text { Difference }\end{array}$} & $\triangle \mathrm{LnCE}$ & $\begin{array}{l}-2.69812 \\
(0.0035)^{* * *}\end{array}$ & $\begin{array}{l}-1.95910 \\
(0.0251)^{* *}\end{array}$ & $\begin{array}{l}20.7872 \\
(0.0226)^{* *}\end{array}$ & $\begin{array}{l}21.1765 \\
(0.0199)^{* *}\end{array}$ & Stationary \\
\hline & $\Delta$ LnpcGDP & $\begin{array}{l}-4.03324 \\
(0.0000)^{* * *}\end{array}$ & $\begin{array}{l}-1.79299 \\
(0.0365)^{* *}\end{array}$ & $\begin{array}{l}20.8073 \\
(0.0225)^{* *}\end{array}$ & $\begin{array}{l}32.4461 \\
(0.0003)^{* * *}\end{array}$ & Stationary \\
\hline & $\Delta \mathrm{S}$ & $\begin{array}{l}-4.68804 \\
(0.0000)^{* * *}\end{array}$ & $\begin{array}{l}-1.83457 \\
(0.0333)^{* *}\end{array}$ & $\begin{array}{l}17.8950 \\
(0.0568)^{* *}\end{array}$ & $\begin{array}{l}21.3395 \\
(0.0188)^{* *}\end{array}$ & Stationary \\
\hline & $\Delta \mathrm{Ur}$ & $\begin{array}{l}-1.67630 \\
(0.0468)^{* *}\end{array}$ & $\begin{array}{l}-1.36916 \\
(0.0855)^{*}\end{array}$ & $\begin{array}{l}14.4950 \\
(0.1516)\end{array}$ & $\begin{array}{l}13.5496 \\
(0.1945)\end{array}$ & Stationary \\
\hline & $\Delta \mathrm{Fes}$ & $\begin{array}{l}-5.53667 \\
(0.0000)^{* * *}\end{array}$ & $\begin{array}{l}-4.11200 \\
(0.0000)^{* * *}\end{array}$ & $\begin{array}{l}34.6729 \\
(0.0001)^{* * *}\end{array}$ & $\begin{array}{l}35.7699 \\
(0.0001)^{* * *}\end{array}$ & Stationary \\
\hline
\end{tabular}

Notes: * Denotes $10 \%$ level of significance; ** Denotes $5 \%$ level of significance; *** Denotes $1 \%$ level of significance.

In general, differenced methods can be further used for non-stationary sequences to determine the stationary of those variables. $\Delta \mathrm{LnCE}, \Delta \mathrm{LnpcGDP}, \Delta \mathrm{S}, \Delta \mathrm{Ur}, \Delta \mathrm{Fes}$ represent those variables at the first difference. From the Table 4 , it can be seen that the unit root test statistic of all variables exceeds the critical value at $10 \%$ level and all these variables are stationary at the first difference, indicating that the null hypothesis that there is a unit root is rejected.

\subsection{Panel Co-integration Test Results}

Because all variables are stationary in the first difference, the Pedroni [22] test can be used to test the panel cointegration. The Pedroni method constructs seven statistics to test the residuals for each province in the group based on the mean value of the single auto-regressive coefficient related to the unit root. From the results in Table 5, among the seven statistics, four are significant at the level of 5\%, revealing that the co-integration relationship exists among the examined variables. Moreover, Kao test and Johansen test are employed to test the co-integration relationship for robust, and the results also support the conclusion that there is a co-integration relationship among the examined variables.

Table 5 Panel co-integration tests results of five provinces in North China

\begin{tabular}{lcl}
\hline & Pedroni residual co-integration test & \\
\hline Test Statistics & Statistics & Prob. \\
\hline Panel v-Statistic & -0.366215 & 0.6429 \\
Panel rho-Statistic & 1.197785 & 0.8845 \\
Panel PP-Statistic & -1.681520 & $0.0463^{* *}$ \\
Panel ADF-Statistic & -1.664685 & $0.0480^{* *}$ \\
Group rho-Statistic & 2.289475 & 0.9890 \\
\hline
\end{tabular}




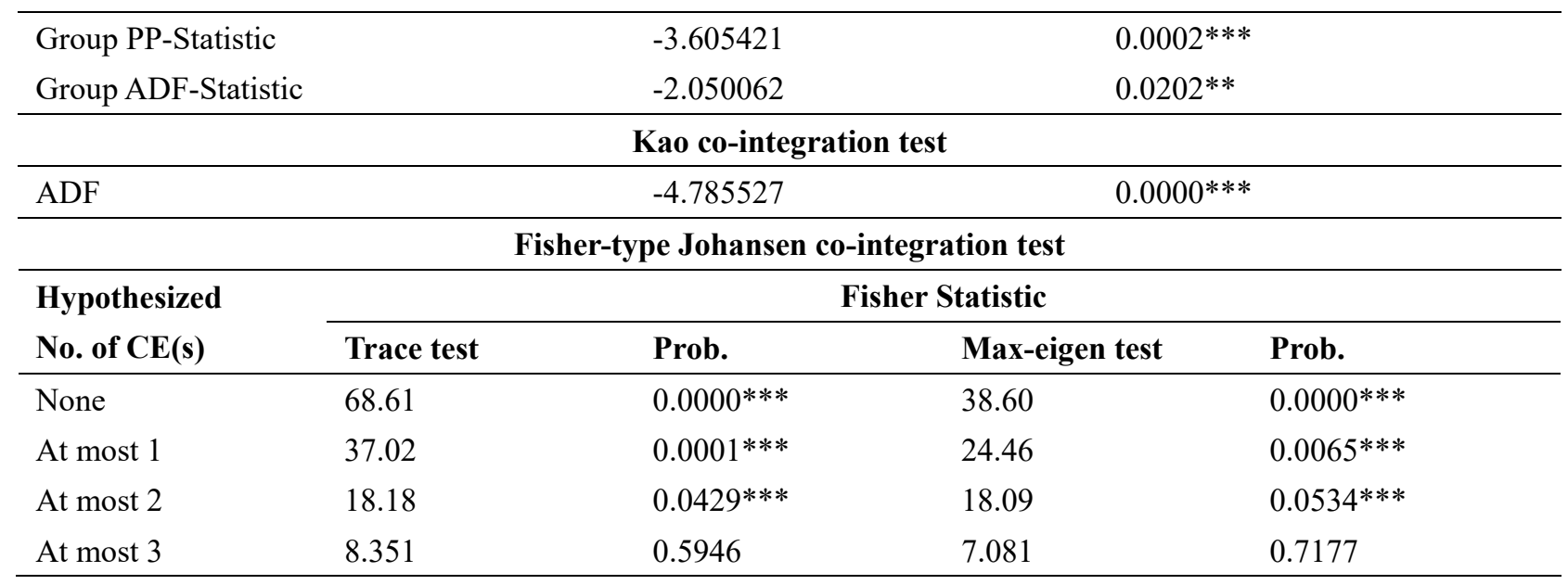

Notes: $* * * * * *$ Denote the rejections of null hypothesis at $10 \%, 5 \%$ and $1 \%$ significance levels, respectively.

\subsection{Model form Determination}

There are two main methods to detect the fixed effect and the random effect, named likelihood ratio (LR) test and Hausman test. The LR test is used to test the fixed effect, and the Hausman test is used to test the random effect. Before estimating the contributions of the fossil energy consumption, industrial structure, urbanization rate and per capita GDP to $\mathrm{CO}_{2}$ emissions, LR test and Hausman test are used to determine the model is the random effect or fixed effect.

Table 6 is the effect test results, from which it can be seen that the cross-section $F$ statistic is larger than the critical value, revealing that the null hypothesis that the fixed effect is redundant can be reject, that is, it is reasonable to introduce the fixed effect. Because the cross-section random statistic of Hausman test is larger than the critical value, it can reject the null hypothesis that the random effect is irrelevant to explanatory variables at the $5 \%$ level of significance. In the same way, the model should be a fixed effect model based on the estimation coefficient of the fixed effect and the random effect as well as the variance values after the difference. Then an $F$-test will be used to select model, including the variable parameter model, the variable intercept model and the contest parameter model. From these models, we can get three different values of the sum squared residual values, which are set to $S_{1}, S_{2}$ and $S_{3}$. The $F$-test value can be obtained by calculating the equation (28) and equation (29). If $F_{1}>F_{1, \alpha}$, the null hypothesis is rejected, which means that the panel data model is not a variable intercept model. If $F_{2}>F_{2, \alpha}$, the null hypothesis is rejected, which means that the panel data model is not a constant parameter model:

$$
\begin{gathered}
F_{1}=\left\{\left(S_{2}-S_{1}\right) /[(N-1) \times K]\right\} /\left\{S_{1} /[N \times T-N \times(K+1)]\right\} \\
F_{2}=\left\{\left(S_{3}-S_{1}\right) /[(N-1) \times(K+1)]\right\} /\left\{S_{1} /[N \times T-N \times(K+1)]\right\}
\end{gathered}
$$

where $S_{1}$ is the variable parameter model residual sum of squares, $S_{2}$ is the variable intercept model residual sum of squares, $S_{3}$ is the sum of the residual squares of the invariant parametric model, $N$ is the number of sections, $K$ is the number of variables, and $T$ is the number of periods. In this paper, $\mathrm{N}=5, \mathrm{~K}=4, \mathrm{~T}=16$, so $(\mathrm{N}-1) \times \mathrm{K}=16, \quad(\mathrm{~N}-1) \times(\mathrm{K}+1)=20, \mathrm{~N} \times \mathrm{T}$ $\mathrm{N} \times(\mathrm{K}+1)=55$.

Table 6 Panel data model effect test results

\begin{tabular}{lll}
\hline \multicolumn{2}{c}{ LR test results } \\
\hline Statistic & Prob. \\
\hline Cross-section F & 74.760141 & $0.0000^{* * *}$ \\
\hline \multicolumn{1}{c}{ Hausman test results } \\
\hline Cross-Section Random & Chi-Square Statistic & Prob. \\
\hline
\end{tabular}




\begin{tabular}{lllll}
\hline Variable & Fixed & Random & Var(Diff.) & Prob. \\
LnpcGDP & 0.234444 & 0.811250 & 0.003951 & $0.0000^{* * *}$ \\
S & 2.398829 & -5.187013 & 0.539484 & $0.0000^{* * *}$ \\
Ur & 2.960566 & 0.066332 & 0.106724 & $0.0000^{* * *}$ \\
Fes & -0.402448 & 0.555015 & 0.088323 & $0.0013 * * *$ \\
\hline
\end{tabular}

Table 7 F-test results (p-values in parentheses)

\begin{tabular}{lllll}
\hline S1 & S2 & S3 & F1 & F2 \\
\hline 0.240369 & 0.875686 & 4.563935 & $9.0856(0.0000)^{* * *}$ & $49.4648(0.0000)^{* * *}$ \\
\hline
\end{tabular}

Notes: $* * *$ Denote the rejections of null hypothesis at $1 \%$ significance levels

\subsection{Panel Data Model Estimation}

According to the above results, we can set up a variable parameter model with fixed effect involving the fossil energy consumption, industrial structure, urbanization rate, per capita GDP in the five provinces of North China. Table 8 is the estimated results of the model. From which it can be seen that the $\mathrm{R}^{2}$ and the adjusted $\mathrm{R}^{2}$ are 0.9951 and 0.9929 , respectively. Besides, the $F$ statistic is significant and each coefficient is positive and significant at the $10 \%$ significance level. Therefore, this model has the advantages of significant, high goodness of fit and good model effect. From the estimated results of the model, we can know that:

(1) In five provinces of North China, except for Inner Mongolia, the urbanization rate makes the largest contributed to $\mathrm{CO}_{2}$ emissions, followed by the industrial structure. The level of urbanization in Inner Mongolia has a negative impact on $\mathrm{CO}_{2}$ emissions, mainly because of the reduction of the negative environmental impacts through the improvement of technology and the reform of industrial structure. The per capita GDP variable is the natural logarithm, and its coefficient can be interpreted as elasticity. The results showed that a $1 \%$ increase in GDP per capita actually increased $\mathrm{CO}_{2}$ emissions in Beijing, Tianjin, Hebei, Shanxi and Inner Mongolia by $-0.18 \%,-0.25 \%, 0.05 \%, 0.16 \%, 1.14 \%$, respectively. It can be seen from the data that the economic development in Beijing and Tianjin can help reduce $\mathrm{CO}_{2}$ emissions. It is because Beijing and Tianjin are mainly developing low-carbon economies such as tertiary industry. In other provinces, especially Inner Mongolia, the economy is relatively backward, and in order to develop the economy, more fossil fuels with high carbon emissions are consumed. From the impact of industrial structure on $\mathrm{CO}_{2}$ emissions, expect Beijing, other provinces are positive, among which Hebei is the highest, and Inner Mongolia is the lowest, because Hebei mainly relies on the secondary industry to develop economy, while Inner Mongolia's economy is underdeveloped, resulting that the proportion of the added value of the secondary industry to GDP is low.

(2) In general, in the provinces where economic growth relies on heavy industry or underdeveloped provinces, the contribution of fossil energy consumption to the growth of $\mathrm{CO}_{2}$ emissions is relatively large. Among them, the contribution rates of Shanxi and Hebei are the highest, because Shanxi and Hebei mainly use fossil energy to develop the economy. A $1 \%$ increase of the fossil energy consumption in these two province increases $\mathrm{CO}_{2}$ emissions by $5.15 \%$ and $7.45 \%$, respectively.

Table 8 The estimated results of the variable parameter model with fixed effect (p-values in parentheses)

\begin{tabular}{llllll}
\hline Variables & Beijing & Tianjin & Hebei & Shanxi & Inner Mongolia \\
\hline LnpcGDP & -0.184666 & -0.252950 & 0.045949 & 0.159132 & 1.141293 \\
\hline
\end{tabular}




\begin{tabular}{llllll}
\hline & $(0.0529) *$ & $(0.0503) *$ & $(0.0415) * *$ & $(0.0964) *$ & $(0.0000) * * *$ \\
\hline \multirow{2}{*}{$\mathrm{S}$} & -2.527673 & 3.258304 & 4.800726 & 2.238717 & 0.399838 \\
& $(0.0114) * *$ & $(0.0546) *$ & $(0.0001) * * *$ & $(0.0110) * *$ & $(0.0260) * *$ \\
\hline \multirow{2}{*}{$\mathrm{Ur}$} & 6.105563 & 14.31894 & 4.905273 & 8.385134 & -8.456532 \\
& $(0.0334) * *$ & $(0.0341) * *$ & $(0.0597) *$ & $(0.0344) * *$ & $(0.0030) * * *$ \\
\hline \multirow{2}{*}{$\mathrm{Fes}$} & 0.524540 & 0.109423 & 5.146342 & 7.453247 & 0.531132 \\
\hline $\mathrm{C}$ & $(0.0386) * *$ & $(0.0884) *$ & $(0.0962) *$ & $(0.0823) *$ & $(0.0620) *$ \\
$\mathrm{R} 2$ & 0.859413 & -6.814882 & 1.82401 & -5.377967 & 5.664071 \\
\hline
\end{tabular}

Notes: $* * * * * *$ Denote the rejections of null hypothesis at $10 \%, 5 \%$ and $1 \%$ significance levels, respectively.

In order to verify the effectiveness of establishing panel data model, the autocorrelation and heteroscedasticity tests need to be performed. In this study, the Wooldridge test is used to test whether there is a correlation between different variable, and the Modified Wald test method is used to check the heteroscedasticity of the different variables. The results are listed in Table 9, showing that there is no sequence correlation and heteroscedasticity, indicating that the model's estimation results are valid.

Table 9 Autocorrelation and heteroscedasticity test results (p-values in parentheses)

\begin{tabular}{lll}
\hline Test Type & Test Method & Statistic \\
\hline Autocorrelation test & Wooldridge test & $3.321(0.1425)$ \\
Heteroscedasticity test & Modified Wald test & $8.76(0.1190)$ \\
\hline
\end{tabular}

\subsection{Panel Granger Causality Test Results}

Table 10 reports the panel Granger causality test results. The contents of which contain asterisks means that the null hypothesis should be rejected at a specified level of significance. In Tianjin, for example, when the null hypothesis is "LnpcGDP does not Granger Cause LnCE", the $F$-test corresponding $p$-value is 0.01 which is less than 0.05 . Therefore, the null hypothesis should be rejected, implying that per capita GDP does Granger cause $\mathrm{CO}_{2}$ emissions. From the results listed in Table 10, we can get the following findings:

(1) From the results of the Granger causality test in the relationship between $\mathrm{CO}_{2}$ emissions and urbanization rate, there is a unidirectional causality running from urbanization rate to $\mathrm{CO}_{2}$ emissions in the five provinces, meaning that urbanization rate does Granger cause $\mathrm{CO}_{2}$ emissions. Therefore, the change of urbanization rate will have an impact on $\mathrm{CO}_{2}$ emissions. Besides, there exists bi-directional causal relationship between $\mathrm{CO}_{2}$ emissions and urbanization rate in Beijing and Tianjin.

(2) From the results of the Granger causality test in the relationship between $\mathrm{CO}_{2}$ emissions and per capita GDP, there is a bidirectional causality between per capita GDP to $\mathrm{CO}_{2}$ emissions in the Tianjin, Hebei and Shanxi, indicating that the feedback hypothesis that $\mathrm{CO}_{2}$ emissions and per capita GDP are interrelated and mutually complementary emerges. Therefore, the policy of developing the economy and increasing the per capita GDP will have an impact on the emissions of $\mathrm{CO}_{2}$, and the management of $\mathrm{CO}_{2}$ emissions will also have an impact on economic development. In Inner Mongolia, there is a unidirectional causality running from per capita GDP to $\mathrm{CO}_{2}$ emissions, supporting the growth hypothesis, that is to say, with the increase of per capita GDP in Inner Mongolia, $\mathrm{CO}_{2}$ emissions will increase. Additionally, Beijing is mainly based on the third industry to develop the economy, and its industry belongs to the low carbon industry, so there is no causal relationship between per capita GDP and $\mathrm{CO}_{2}$ emissions.

(3) Except for Hebei and Beijing, there is a unidirectional relationship between fossil energy consumption and $\mathrm{CO}_{2}$ emissions. Because Beijing as a developed area with more service industries, its development is mainly based on electric power, and fossil energy consumption is relatively low. Therefore, there is no causal relationship between fossil energy 
411 consumption and $\mathrm{CO}_{2}$ emissions in Beijing. In Tianjin, Hebei, and Shanxi, there is a unidirectional relationship from $\mathrm{CO}_{2}$ 412 emissions to industrial structure, which means $\mathrm{CO}_{2}$ emissions can promote the adjustment of industrial structure in these 413 provinces.

414 (4) From the whole region of North China, there are bi-direction causalities between $\mathrm{CO}_{2}$ emissions and per capita GDP, and between $\mathrm{CO}_{2}$ emissions and urbanization rate. Besides, the unidirectional causal relationships from fossil energy consumption to $\mathrm{CO}_{2}$ emissions and from industrial structure to $\mathrm{CO}_{2}$ emissions are found, revealing that fossil energy consumption and industrial structure have significant influences on $\mathrm{CO}_{2}$ emissions in North China.

Table 10 Results of Granger causality tests ( $\mathrm{p}$-values in parentheses)

\begin{tabular}{|c|c|c|c|c|c|c|}
\hline Null Hypothesis & Beijing & Tianjin & Hebei & Shanxi & $\begin{array}{c}\text { Inner } \\
\text { Mongolia }\end{array}$ & $\begin{array}{l}\text { North } \\
\text { China }\end{array}$ \\
\hline $\begin{array}{l}\text { LnpcGDP does not } \\
\text { Granger Cause LnCE }\end{array}$ & $\begin{array}{l}0.98818 \\
(0.4093)\end{array}$ & $\begin{array}{c}6.12997 \\
(0.0209)^{* *}\end{array}$ & $\begin{array}{c}5.47498 \\
(0.0278)^{* *}\end{array}$ & $\begin{array}{l}3.06865 \\
(0.0964)^{*}\end{array}$ & $\begin{array}{c}3.77584 \\
(0.0645)^{*}\end{array}$ & $\begin{array}{c}9.42479 \\
(0.0003)^{* *} \\
*\end{array}$ \\
\hline $\begin{array}{l}\text { LnCE does not } \\
\text { Granger Cause LnpcGDP }\end{array}$ & $\begin{array}{l}5.06632 \\
(0.9363)\end{array}$ & $\begin{array}{c}5.96870 \\
(0.0224)^{* *}\end{array}$ & $\begin{array}{c}9.58697 \\
(0.0059)^{* *} \\
*\end{array}$ & $\begin{array}{c}3.46694 \\
(0.0765)^{*}\end{array}$ & $\begin{array}{l}5.55442 \\
(0.5928)\end{array}$ & $\begin{array}{c}4.13813 \\
(0.0203)^{* *}\end{array}$ \\
\hline $\begin{array}{c}\text { Fes does not } \\
\text { Granger Cause LnCE }\end{array}$ & $\begin{array}{l}0.49467 \\
(0.6254)\end{array}$ & $\begin{array}{l}0.56397 \\
(0.5878)\end{array}$ & $\begin{array}{l}2.93316 \\
(0.1045)\end{array}$ & $\begin{array}{l}1.03915 \\
(0.3926)\end{array}$ & $\begin{array}{l}1.19854 \\
(0.3456)\end{array}$ & $\begin{array}{c}10.6013 \\
(0.0001)^{* *} \\
*\end{array}$ \\
\hline $\begin{array}{c}\text { LnCE does not } \\
\text { Granger Cause Fes }\end{array}$ & $\begin{array}{l}0.14616 \\
(0.8660)\end{array}$ & $\begin{array}{c}4.37885 \\
(0.0470)^{* *}\end{array}$ & $\begin{array}{c}5.69709 \\
(0.0251)^{* *}\end{array}$ & $\begin{array}{c}4.86519 \\
(0.0370)^{* *}\end{array}$ & $\begin{array}{c}6.66724 \\
(0.0167)^{* *}\end{array}$ & $\begin{array}{l}0.29003 \\
(0.7492)\end{array}$ \\
\hline $\begin{array}{c}\text { S does not } \\
\text { Granger Cause LnCE }\end{array}$ & $\begin{array}{l}0.08017 \\
(0.9236)\end{array}$ & $\begin{array}{l}0.81149 \\
(0.4742)\end{array}$ & $\begin{array}{l}0.07144 \\
(0.9316)\end{array}$ & $\begin{array}{l}0.16196 \\
(0.8529)\end{array}$ & $\begin{array}{l}2.80225 \\
(0.1132)\end{array}$ & $\begin{array}{c}4.47315 \\
(0.0151)^{* *}\end{array}$ \\
\hline $\begin{array}{l}\text { LnCE does not } \\
\text { Granger Cause S }\end{array}$ & $\begin{array}{l}1.51918 \\
(0.2701) \\
\end{array}$ & $\begin{array}{c}5.76465 \\
(0.0245)^{* *}\end{array}$ & $\begin{array}{c}6.09861 \\
(0.0212)^{* *}\end{array}$ & $\begin{array}{c}4.21023 \\
(0.0512)^{*}\end{array}$ & $\begin{array}{l}0.42433 \\
(0.6666)\end{array}$ & $\begin{array}{l}1.91107 \\
(0.1561)\end{array}$ \\
\hline $\begin{array}{l}\text { Ur does not } \\
\text { Granger Cause LnCE }\end{array}$ & $\begin{array}{c}12.18178 \\
(0.0026)^{* *}\end{array}$ & $\begin{array}{c}10.94885 \\
(0.0039)^{* *}\end{array}$ & $\begin{array}{c}6.67948 \\
(0.0167)^{* *}\end{array}$ & $\begin{array}{c}3.42330 \\
(0.0784)^{*}\end{array}$ & $\begin{array}{l}3.00803 \\
(0.0999)^{*}\end{array}$ & $\begin{array}{c}13.9660 \\
(0.0000)^{* *} \\
*\end{array}$ \\
\hline $\begin{array}{l}\text { LnCE does not } \\
\text { Granger Cause Ur }\end{array}$ & $\begin{array}{c}6.77116 \\
(0.0160)^{* *}\end{array}$ & $\begin{array}{c}8.31398 \\
(0.0090)^{* *}\end{array}$ & $\begin{array}{l}2.94618 \\
(0.1037)\end{array}$ & $\begin{array}{l}0.50370 \\
(0.6204)\end{array}$ & $\begin{array}{l}0.05593 \\
(0.9459)\end{array}$ & $\begin{array}{c}10.15619 \\
(0.0049) \\
* * *\end{array}$ \\
\hline $\begin{array}{c}\text { Fes does not } \\
\text { Granger Cause LnpcGDP }\end{array}$ & $\begin{array}{l}0.46363 \\
(0.6432)\end{array}$ & $\begin{array}{l}0.33945 \\
(0.7209)\end{array}$ & $\begin{array}{l}1.88487 \\
(0.2071)\end{array}$ & $\begin{array}{c}11.2426 \\
(0.0036)^{* *} \\
*\end{array}$ & $\begin{array}{l}0.22543 \\
(0.8025)\end{array}$ & $\begin{array}{l}0.38226 \\
(0.6838)\end{array}$ \\
\hline $\begin{array}{l}\text { LnpcGDP does not } \\
\text { Granger Cause Fes }\end{array}$ & $\begin{array}{l}2.15123 \\
(0.1723)\end{array}$ & $\begin{array}{c}8.04270 \\
(0.0099)^{* *} \\
*\end{array}$ & $\begin{array}{l}0.41506 \\
(0.6723)\end{array}$ & $\begin{array}{c}8.80355 \\
(0.0076)^{* *} \\
*\end{array}$ & $\begin{array}{c}6.15488 \\
(0.0207)^{* *}\end{array}$ & $\begin{array}{l}0.06942 \\
(0.9330)\end{array}$ \\
\hline $\begin{array}{c}\text { S does not } \\
\text { Granger Cause LnpcGDP }\end{array}$ & $\begin{array}{l}0.80540 \\
(0.4767)\end{array}$ & $\begin{array}{l}1.97251 \\
(0.1948)\end{array}$ & $\begin{array}{l}0.37596 \\
(0.6969)\end{array}$ & $\begin{array}{l}2.99672 \\
(0.1006)\end{array}$ & $\begin{array}{l}1.81168 \\
(0.2182)\end{array}$ & $\begin{array}{c}5.02806 \\
(0.0093)^{* *} \\
*\end{array}$ \\
\hline $\begin{array}{c}\text { LnpcGDP does not } \\
\text { Granger Cause S }\end{array}$ & $\begin{array}{c}12.7091 \\
(0.0024)^{* *} \\
*\end{array}$ & $\begin{array}{c}4.60446 \\
(0.0420)^{* *}\end{array}$ & $\begin{array}{c}3.13706 \\
(0.0925)^{*}\end{array}$ & $\begin{array}{c}6.57866 \\
(0.0173)^{* *}\end{array}$ & $\begin{array}{l}0.32774 \\
(0.7288)\end{array}$ & $\begin{array}{c}6.27785 \\
(0.0032)^{* *} \\
*\end{array}$ \\
\hline
\end{tabular}




\begin{tabular}{ccccccc}
\hline Ur does not & 1.01445 & 1.21191 & 6.04704 & 0.48501 & 2.47257 & 0.80983 \\
Granger Cause LnpcGDP & $(0.4006)$ & $(0.3419)$ & $(0.0216)^{* *}$ & $(0.6309)$ & $(0.1394)$ & $(0.4494)$ \\
\hline LnpcGDP does not & 1.25366 & 3.11088 & 0.24697 & 2.69804 & 21.6700 & 0.22170 \\
Granger Cause Ur & $(0.3309)$ & $(0.0940)^{*}$ & $(0.7863)$ & $(0.1208)$ & $\begin{array}{c}(0.0004)^{* *} \\
*\end{array}$ & $(0.8018)$ \\
\hline S does not & 0.75053 & 1.28933 & 0.49909 & 1.98950 & 6.73755 & 0.11159 \\
Granger Cause Fes & $(0.4995)$ & $(0.3218)$ & $(0.6229)$ & $(0.1925)$ & $(0.0163)^{* *}$ & $(0.8946)$ \\
\hline Fes does not & 0.87298 & 7.74971 & 1.51612 & 7.58513 & 0.24263 & 1.79494 \\
Granger Cause S & $(0.4503)$ & $(0.0110)^{* *}$ & $(0.2707)$ & $(0.0117)^{* *}$ & $(0.7895)$ & $(0.1743)$ \\
\hline Ur does not & 0.00102 & 3.43762 & 1.34397 & 2.59740 & 4.30505 & 0.22391 \\
Granger Cause Fes & $(0.9990)$ & $(0.0778)^{*}$ & $(0.3085)$ & $(0.1287)$ & $(0.0488)^{* *}$ & $(0.8000)$ \\
\hline Fes does not & 0.84314 & 1.51819 & 1.34832 & 0.13179 & 0.86967 & 3.48275 \\
Granger Cause Ur & $(0.4617)$ & $(0.2703)$ & $(0.3075)$ & $(0.8782)$ & $(0.4515)$ & $(0.0366)^{* *}$ \\
\hline Ur does not & 2.33202 & 3.93288 & 8.66108 & 7.28835 & 1.02554 & 1.63503 \\
Granger Cause S & $(0.1528)$ & $(0.0592)^{*}$ & $(0.0080)^{* *}$ & $(0.0131)^{* *}$ & $(0.3970)$ & $(0.2029)$ \\
\hline S does not & 4.00355 & 2.49891 & 7.21363 & 0.49523 & 2.05464 & 0.23175 \\
Granger Cause Ur & $(0.0571)^{*}$ & $(0.1370)$ & $(0.0135)^{* *}$ & $(0.6251)$ & $(0.1841)$ & $(0.7938)$ \\
\hline
\end{tabular}

Notes: $* * * * * *$ Denote the rejections of null hypothesis at $10 \%, 5 \%$ and $1 \%$ significance levels, respectively.

\section{Conclusion and Policy Implications}

China has made great achievements in economic development over the past decades, but the $\mathrm{CO}_{2}$ emissions are becoming more and more serious. Under such circumstances, China has promised to substantially reduce carbon emissions in the next 30 years. Therefore, it's necessary exploring the nexus between $\mathrm{CO}_{2}$ emissions, fossil energy consumption, industrial structure, urbanization rate and per capita GDP in North China, including Beijing, Tianjin, Hebei, Shanxi and Inner Mongolia. In this article, the above objectives were accomplished by collecting relevant data from 2004 to 2019 and using panel econometric analysis techniques.

The results of the cross-sectional dependence test suggested that there was no cross-sectional dependence across the panel. The unit root test results clearly indicated that all variables were non-stationary at the level but stationary at their first different. Then, we employed Pedroni's panel co-integration test, Kao co-integration test and Fisher-type Johansen cointegration test to conduct panel cointegration test, showing that all variables were cointegrated in the long run. On this basis, the LR test method and the Hausman test method were used to determine the form of the model. After the panel data model was established, the contribution of various factors to $\mathrm{CO}_{2}$ emissions was analyzed by studying the coefficient of each variable in each province. According to the model estimation results, the urbanization rate contributed most to $\mathrm{CO}_{2}$ emissions, followed by the fossil energy consumption. Finally, the panel Granger causality test revealed that there existed bi-directional causal relationships between $\mathrm{CO}_{2}$ emissions and urbanization rates in Beijing and Tianjin, and unidirectional causal relationships from $\mathrm{CO}_{2}$ emissions to urbanization rates in other regions. In addition, there existed unidirectional causal relationship from industrial structure to $\mathrm{CO}_{2}$ emissions in North China, reverse causalities in Tianjin, Hebei and Shanxi and no causality in Beijing and Inner Mongolia.

Based on the empirical results, several policy recommendations are put forward. Firstly, China should reduce fossil energy consumption and develop sustainable energy source. The proposal of energy saving and emission reduction policy is mainly from the issue of $\mathrm{CO}_{2}$ emissions caused by fossil energy combustion. According to the Granger causality results, it is known that this problem should be paid attention in North China, especially in Shanxi. Therefore, we must reduce the use of fossil fuels and focus on developing clean and renewable energy like wind energy and solar energy. Through these measures, we can not only reduce $\mathrm{CO}_{2}$ emissions in North China, but also achieve green GDP growth. The results of 
Granger causality showed that there was a causal relationship between the per capita GDP and $\mathrm{CO}_{2}$ emissions in North China except Beijing, so the growth of green GDP will help to weaken this causality and make the North China's economy develop sustainably. Secondly, we must constantly improve energy efficiency and promote industrial structural upgrading. Some provinces, such as Hebei and Shanxi, mainly rely on heavy industry to develop the economy. We should promote the reform of the industrial structure, and increase the proportion of the tertiary industry, which will help to reduce the emission of $\mathrm{CO}_{2}$. Besides, the government should improve energy saving technology, and incite thermal power generation to achieve cleaner production. Finally, in the five provinces of North China, we should focus on improving the urbanization rate, and at the same time, we should also consider the actual bearing capacity of the region so as to achieve the goal of rational development, which is also conductive to reducing $\mathrm{CO}_{2}$ emissions.

\section{Declarations :}

Ethics approval and consent to participate: Not applicable.

Consent for publication: Not applicable.

Availability of data and materials: The datasets used and/or analyzed during the current study are available from the corresponding author on reasonable request.

Competing interests: The authors declare that they have no competing interests.

Funding: This study is supported by National Key R\&D Program of China (2020YFB1707800).

Authors' contributions: Dongxiao Niu guided the research, established the model and implemented the simulation; Zhuoya Siqin wrote this article; Mingyu Li and Hao Zhen checked the language; Xiaolong Yang collect data.

Acknowledgements: Thanks are due to the North China Electric Power University Library for providing detailed reference for our research, and this paper was support by the National Key R\&D Program of China (2020YFB1707800).

\section{References}

Akarca A T, Long T V I. Relationship between energy and GNP: a re-examination[J]. Journal of Energy Finance \& Development, 1980, 5:2(2).

Al-Mulali U. Investigating the impact of nuclear energy consumption on GDP growth and CO 2, emissions: A panel data analysis[J]. Progress in Nuclear Energy, 2014, 73(5):172-178.

Amri F. The relationship amongst energy consumption (renewable and non-renewable), and GDP in Algeria[J]. Renewable \& Sustainable Energy Reviews, 2017, 76:62-71.

Bhat T A, Lone T A, Dar K H . The co-integration and causal relationship between saving and economic growth in India[J]. Theoretical and Applied Economics, 2021, xxii(2021).

Boamah K B, Du J, Bediako I A, et al. Carbon dioxide emissions and economic growth of China-the role of international trade[J]. Environmental Science \& Pollution Research, 2017, 24(14):13049-13067.

Breitung, J. The Local Power of Some Unit Root Tests for Panel Data; Discussion Papers, Interdisciplinary Research Project 373: Quantification and Simulation of Economic Processes; Humboldt University Berlin: Berlin, Germany, 1999.

Breusch T S, Pagan A R. The Lagrange multiplier test and its applications to model specification in econometrics[J]. The Review of Economic Studies, 1980, 47(1): 239-253.

Chaudhry I S, Farooq F, Nasim I. Long Run Panel Data Analysis of Energy Consumption and Real GDP of South Asian Economies[J]. Pakistan Journal of Social Sciences, 2015.

Cialani C. CO2 emissions, GDP and trade: a panel co-integration approach[J]. Economics, 2017. 
Cobb C W, Douglas P H. A Theory of Production[J]. American Economic Review, 1928, 18(1):139-165.

Destek M A. Renewable energy consumption and economic growth in newly industrialized countries: Evidence from asymmetric causality test[J]. Renewable Energy, 2016, 95:478-484.

Dogan E, Aslan A. Exploring the relationship among CO 2, emissions, real GDP, energy consumption and tourism in the EU and candidate countries: Evidence from panel models robust to heterogeneity and cross-sectional dependence[J]. Renewable \& Sustainable Energy Reviews, 2017, 77:239-245.

Esfahani M N, Rasoulinezhad E. Will be there New CO2 Emitters in the Future? Evidence of Long-run Panel Cointegration for N-11 Countries[J]. Social Science Electronic Publishing, 2015, 6(3):463-470.

Etokakpan M U , Osundina O A, Bekun F V , et al. Rethinking electricity consumption and economic growth nexus in Turkey: environmental pros and cons[J]. Environmental Science and Pollution Research, 2020, 27(31):39222-39240.

Faisal, Turgut Tursoy, Nil Gunsel Resatoglu. Energy Consumption, Electricity, and GDP Causality; The Case of Russia, 1990-2011 گ[J]. Procedia Economics \& Finance, 2016, 39:653-659.

Farhani S, Shahbaz M, Arouri M E H. Panel analysis of CO2 emissions, GDP, energy consumption, trade openness and urbanization for MENA countries[J]. Mpra Paper, 2013.

Griffith D A. Spatial Econometrics: Methods and Models[J]. Economic Geography, 1988, 65(2):160-162.

Hadri, K. Testing for stationarity in heterogeneous panel data. Econom. J. 2000, 3, 148-161.

Im, K.S.; Pesaran, M.H.; Shin, Y. Testing for unit roots in heterogeneous panels. J. Econom. 2003, 115, 53-74

JLS Lim. CO2Emissions, Energy Consumption and Economic Growth in Malaysia: A Cointegration Approach[J]. University of Nottingham,2017.

Kahia M, Aïssa M S B, Lanouar C. Renewable and non-renewable energy use - economic growth nexus: The case of MENA Net Oil Importing Countries[J]. Renewable \& Sustainable Energy Reviews, 2017, 71:127-140.

Kasman A, Duman Y S. CO2 emissions, economic growth, energy consumption, trade and urbanization in new EU member and candidate countries: A panel data analysis[J]. Economic Modelling, 2015, 44(44):97-103.

Kraft, J.; Kraft,A. On the relationship between energy and GNP. J. Energy Dev. 1978,3,401-403.

Levin A, Lin C F, Chu C S J. Unit root tests in panel data: asymptotic and finite-sample properties[J]. Journal of Econometrics, 2004, 108(1):1-24.

Li J, Chen L, Xiang Y, et al. Influencing Factors and Development Trend Analysis of China Electric Grid Investment Demand Based on a Panel Co-Integration Model[J]. Sustainability, 2018.

Li Y, Peng H, Yasmeen R, et al. Energy consumption and financial development indicators nexuses in Asian economies: a dynamic seemingly unrelated regression approach[J]. Environmental Science and Pollution Research, 2020.

Lluís Carrion-i-Silvestre, J.; Barrio-Castro, D.; López-Bazo, E. Breaking the panels: An application to the GDP per capita. Econom. J. 2005, 8, 159-175.

Margarita Robaina-Alves, Victor Moutinho, Rui Costa. Change in energy-related CO2 (carbon dioxide) emissions in Portuguese tourism: a decomposition analysis from 2000 to 2008[J]. Journal of Cleaner Production,2016,111.

Mohanty A, Chaturvedi D. Relationship between Electricity Energy Consumption and GDP: Evidence from India[J]. International Journal of Economics \& Finance, 2015, 7(2).

Narayan P K, Popp S. The energy consumption-real GDP nexus revisited: Empirical evidence from 93 countries[J]. Economic Modelling, 2012, 29(2):303-308.

Ouyang X, Lin B. Carbon dioxide (CO 2) emissions during urbanization: A comparative study between China and Japan[J]. Journal of Cleaner Production, 2017, 143:356-368.

Oyaromade R, Mathew A, Abalaba B P. Energy Consumption and Economic Growth in Nigeria: A Causality Analysis[J]. International Journal of Sustainable Energy \& Environmental Research, 2014, 3(1):53-61.

Ozturk I, Acaravci A. CO2 emissions, energy consumption and economic growth in Turkey[M]// Renewable and Sustainable Energy Reviews. 2010:3220-3225. 
Pedroni P. Critical Values for Cointegration Tests in Heterogeneous Panels with Multiple Regressors[J]. Oxford Bulletin of Economics \& Statistics, 1999, 61(S1):653-670.

Pedroni P. Panel Cointegration: Asymptotic and Finite Sample Properties of, Pooled Time Series Tests with an Application to The ppp Hypothesis[J]. Department of Economics Working Papers, 2004, 20(3):597-625.

Qazi U, Alam A, Ahmad S, et al. Impact of FDI and Electricity on the Economic Growth of Pakistan: A Long Run Cointegration and Causality Analysis[J]. Research in World Economy, 2021, 12(2):273-288.

Saidi K, Mbarek M B. Nuclear energy, renewable energy, CO 2, emissions, and economic growth for nine developed countries: Evidence from panel Granger causality tests[J]. Progress in Nuclear Energy, 2016, 88:364-374.

Salari M , Javid R J , Noghanibehambari H . The nexus between CO 2 emissions, energy consumption, and economic growth in the U.S[J]. Economic Analysis and Policy, 2021, 69:182-194.

Saleh I, Abedi S, Abedi S. A panel data approach for investigation of gross domestic product (GDP) and CO2 causality relationship[J]. Journal of Agricultural Science \& Technology, 2014, 16(5):947-956.

Sulaiman C, Abdulrahim A S. The relationship between CO2 emissions, energy consumption and economic growth in Malaysia: a three-way linkage approach[J]. Environmental Science \& Pollution Research, 2017, 24(32):1-17.

Vafaeirad M, Mohammadiha M, Goodarzy Y. Energy Consumption and GDP in Selected Asian Countries: A Cointegrated Panel Analysis[J]. Journal of Asian Scientific Research, 2015, 5(4):177-184.

Van G . Equilibrium in the Production Process of a Two-Sector Model of the New Economy[J]. MPRA Paper, 2021.

Wang S, Fang C, Guan X, et al. Urbanization, energy consumption, and carbon dioxide emissions in China: A panel data analysis of China's provinces[J]. Applied Energy, 2014, 136(C):738-749.

Wang S, Li Q, Fang C, et al. The relationship between economic growth, energy consumption, and CO 2, emissions: Empirical evidence from China[J]. Science of the Total Environment, 2016, 542(Pt A):360-371.

Wang Y, Chen L, Kubota J. The relationship between urbanization, energy use and carbon emissions: evidence from a panel of Association of Southeast Asian Nations (ASEAN) countries[J]. Journal of Cleaner Production, 2016, 112:13681374.

Wang Y, Li L, Kubota J, et al. Does urbanization lead to more carbon emissions? Evidence from a panel of BRICS countries[J]. Applied Energy, 2016, 168:375-380.

Wang Y, Wang Y, Zhou J, et al. Energy consumption and economic growth in China: A multivariate causality test[J]. Energy Policy, 2011, 39(7):4399-4406.

$\mathrm{Xu}$ H, Zhang W. The causal relationship between carbon emissions and land urbanization quality: A panel data analysis for Chinese provinces[J]. Journal of Cleaner Production, 2016, 137:241-248.

Yakubu M M, Jelilov G, Yakubu M M, et al. Effect of Energy Consumption on GDP Evidence from (Ten) Sub-Saharan Africa Countries[J]. 2017, 3(5):3-14.

Zaman K, Shahbaz M, Loganathan N, et al. Tourism development, energy consumption and Environmental Kuznets Curve: Trivariate analysis in the panel of developed and developing countries[J]. Tourism Management, 2016, 54:275-283.

Zhang $\mathrm{W}, \mathrm{Xu} \mathrm{H}$. Effects of land urbanization and land finance on carbon emissions: A panel data analysis for Chinese provinces[J]. Land Use Policy, 2017, 63:493-500.

Zhang W, Zhang J S, Yuan X P. Industrialization, Economic Growth and Energy Consumption:An Empirical Research Based on the Provincial Panel Data[J]. Statistics \& Information Forum, 2012. 